\title{
MATHEMATICS EDUCATOR TEACHER STORIES
}

SIGNE E. KASTBERG

Purdue University

ELIZABETH SUAZO-FLORES

Purdue University

\section{SUE ELLEN RICHARDSON}

Purdue University

ABSTRACT Teacher stories/autobiographies have been used by mathematics teacher educators (MTES) to gain insight into prospective teachers' (PTs) experience with mathematics, yet stories of MTEs' motivation for and learning by engaging PTs in creating teacher stories is less understood. We fill this gap by narrating our experiences gaining insight into motivations for engaging PTs in creating teacher stories. Artifacts from our teaching practice, discussions of the work of Dewey and Rogers, and reflections were used to create themes that informed the plot line of each narrative. Findings focus on ways that teacher stories sustain PTs and MTEs by creating a living counter-narrative to the narrative of teacher evaluation MTEs and PTs live in the United States. We argue that MTEs' motivations for collecting PTs' teacher stories are informed by MTEs' life experiences and the development of MTEs' views of teaching and learning to teach.

Keywords: Prospective Teachers. Autobiography. Mathematics Teacher Educator.

\section{RESUMO HISTÓRIAS DE EDUCADORES DE PROFESSORES DE MATEMÁTICA}

Histórias de professores/autobiografias têm sido usadas por educadores de professores de matemática para obter insights sobre a experiência dos futuros professores com a matemática. No entanto, as histórias de motivação e aprendizado de educadores de professores de matemática, envolvendo futuros professores na criação de histórias de professores, são menos compreendidas. Nós preenchemos essa lacuna narrando nossas experiências, obtendo "insights" sobre motivações para envolver futuros professores na criação de histórias de professores. Artefatos de nossa prática de ensino, discussões sobre o trabalho de Dewey e Rogers e reflexões foram usadas para criar 
temas que informavam o enredo de cada narrativa. Os resultados concentram-se em maneiras pelas quais as histórias de professores sustentam os futuros professores e os educadores de professores de matemática, criando uma contranarrativa viva para a narrativa de avaliação desses docentes nos Estados Unidos. Argumentamos que as motivações dos educadores de professores de matemática para a coleta de histórias de futuros professores são informadas pelas experiências de vida desses educadores e pelo desenvolvimento das suas visões de ensino e aprendizagem.

Palavras-chave: Futuros professores de matemática. Autobiografia. Educadores de professores de matemática.

\section{RESUMEN HISTORIAS DE EDUCADORES DE PROFESORES DE MATEMÁTICAS}

Las historias de profesores/autobiografias han sido usadas por educadores de profesores de matemáticas para obtener información sobre la experiencia de los futuros profesores con las matemáticas, sin embargo, las historias de motivación y aprendizaje de los educadores de profesores de matemáticas que involucra a futuros profesores en la creación de historias de profesores los profesores son menos comprendidos. Nosotros llenamos esa brecha narrando nuestras experiencias, obteniendo "insights" sobre motivaciones para involucrar a futuros profesores en la creación de historias de profesores. Los artefactos de nuestra práctica de enseñanza, discusiones sobre el trabajo de Dewey y Rogers y reflexiones se utilizaron para crear temas que informaban la trama de cada narrativa. Los resultados se concentran en maneras en que las historias de profesores sostienen a los futuros profesores y educadores de profesores de matemáticas creando una contra-narrativa viva para la narrativa de evaluación de ellos en los Estados Unidos. Argumentamos que las motivaciones de los educadores de profesores de matemáticas para la recolección de historias de futuros profesores son informadas por las experiencias de vida de esos educadores y por el desarrollo de las visiones de enseñanza y aprendizaje para enseñar de ellos.

Palabras clave: Futuros professores de matemática. Autobiografia. Educadores de profesores de Matemáticas.

Mathematics teacher educators (MTEs) have used mathematics autobiographies/teacher stories to gain insight into teachers' experiences with mathematics and with teaching (DRAKE, 2006; MARSHALL \& CHAO, 2018; SCHIFTER \&
FOSNOT, 1993). Yet what motivates the MTES collection of teacher stories and the impact of engaging PTs in teachers' stories is seldom reported. In this paper, we address this gap in the literature by sharing narratives of three 
MTEs constructed to share findings from an analysis of the development and evolution of a teacher story assignment, feedback given to prospective teachers (PTs) on teacher stories, and recordings of conversations about writings from Dewey and Rogers. The narratives were constructed using a plot line informed by themes drawn from readings of and listening to the data. Findings focus on ways that teacher stories sustain PTs and MTEs by creating a living counter-narrative to the narrative of teacher evaluation MTEs and PTs live in the United States. We argue that MTEs' motivations for collecting PTs' teacher stories are informed MTEs' life experiences and the development of MTEs' views of teaching and learning to teach.

\section{Contexts for Autobiography/ Memory Work in Mathematics Teacher Education}

Autobiography and memory work has a past, present, and future in mathematics teacher education. For each MTE, one's past, present, and future create a unique context that informs the sensory experience (written or recorded stories, images, verbal communications, spatial experiences, etcetera) of engaging with PTs' stories. To understand MTEs' experiences with autobiography, we share three contexts that inform our work: teacher stories in mathematics teacher education research literature, teacher stories as a way of knowing, and our contexts as MTEs.

\section{Context of Autobiography in Mathematics Teacher Education Literature}

Teacher stories, or mathematics autobiographies, are often used as assignments in mathematics methods courses (e.g., LOPRESTO \& DRAKE, 2005; MARSHALL \& CHAO, 2017). In these stories, teachers write about their experiences as learners of mathematics and episodes in their lives that brought them to the teaching profession. Teachers' memories of learning mathematics have been identified as informing their views of teaching mathematics (e.g., DRAKE, 2006; DRAKE \& SHERIN, 2006; MEWBORN, 2000). This finding has led to the use of teacher stories as levers for change in emerging practice (de FREITAS, 2008; MARSHALL \& CHAO, 2018). For example, Marshall and Chao describe the use of teacher stories as a way to build attention to learners and their experiences in mathematics methods courses. Such use of teacher stories in mathematics education has been associated with practices teachers use (DRAKE \& SHERIN, 2006) and is one motivation for MTEs' use of teacher stories as levers for PTs' change. Yet we wonder if the use of stories might be motivated by other MTE desires to know and ways of knowing.

MTEs collect, read, and provide spaces for teachers to share stories, explore teachers' relationship with mathematics, and gather background information to make relevant curriculum for teachers (e.g., DRAKE, 2006; DRAKE \& SHERIN, 2006; LOPRESTO \& DRAKE, 2005; MARSHALL \& CHAO, 2018). However, MTEs' reactions, insights and interpretations of these stories are in relation to their own teacher stories, experiences, and professional knowledge. Scholarly inquiry (LEE \& MEWBORN, 2009) into MTEs' teaching practices has the potential to reveal ways that MTEs use teacher stories and develop their use in teaching about teaching (LOUGHRAN, 2004).

Analyzing teacher stories can provoke awakening experiences (CONNELLY \& CLANDININ, 1994, 1995) for MTEs. The concept of awakening is aligned with Dewey's (1938) principle of continuity of experience and refers to "becoming aware of the possibility of seeing oneself and the world in new ways" (CONNELLY \& 
CLANDININ, 1995, p. 82). As MTEs interact with teachers, stories teachers tell resonate with MTEs' experiences and contribute to new understandings of their practice. In mathematics education, MTEs have narrated awakening experiences (NOLAN, 2010; TZUR, 2001). Mentoring a graduate student to teach a mathematics methods course, awakened Tzur (2001) to a need for conceptualizing his role as MTE as researcher and learner of his practice. While being the instructor of a new inquiry-based pedagogical approach mathematics content course, Nolan (2010) awakened to the risks of embracing ambiguity, uncertainty, and unpredictability as her PTs demanded to be taught and evaluated from a teacher-centered approach. These two MTEs awakened to a need to feel sustained by portraying themselves as learners of their practice.

\section{Teacher Stories as a Way of Knowing Based on Knowledge Landscapes}

Teacher educators are typically positioned as orchestrators of opportunities to learn and PTs as the ones who learn from them. This mainstream discourse has its origins in the emphasis of technical rationality in education (SCHON, 1983). It is understood that, "knowing precedes doing; action is a consequence of knowing; the highest form of knowing is propositional" (DOYLE \& CARTER, 2003, p. 133). Yet, teacher educators have acknowledged their struggles in keeping up with this imposed role (e.g., CLANDININ, 1995; Elbaz, 2014). One of the struggles comes from knowing that our PTs carry histories and will live stories, which will inform their ways of being in their future classrooms. At the same time, MTEs understand that PTs will have to find ways to operate in the school system and local community that enable them to feel sustained in their work.
PTs' knowledge for living and teaching includes propositional knowledge but moves beyond that to include experiential knowledge. As radical constructivist teacher educators (D'AMBROSIO \& KASTBERG, 2012), we acknowledge that we will never know our PTs' histories and cannot teach propositional knowledge that will be sufficient to support PTs' to learn what they need to know to be successful in their future classrooms. Additionally, in our search to be supportive of our PTs, we have come to conceive PTs' teaching stories as a method (CLANDININ \& CONNELLY, 1994) that allows us to know about them in relation to us. Through PTs' stories, we can learn about their practical knowledge (ELBAZ, 1981), which at the same time helps us to understand their journeys as becoming teachers (DOYLE \& CARTER, 2003).

We conceive the study of education as the exploration of people's experiences (DEWEY, 1938). Writing and reading stories are a way of knowing about someone's experiences. Stories are descriptions of events in chronological ways with characters and contexts that convey a message (CARTER, 1993). Stories are essential for us. Stories provide us with information that is not possible to know from statistical measures or propositional statements. For instance, through stories we know about people's thinking, feelings, hopes, and fears of events. In other words, through stories, we learn about people's ways of knowing. Our stories begin with our contexts.

\section{Our Contexts and Teacher Stories}

In this section, we share the authors' context for autobiography in mathematics teacher education. In particular, each story briefly describes the role of the author as she positioned herself to learn about autobiography in mathematics teacher education. Each of the stories happened in the same time, but not the 
same space. In particular the three of us were all teacher educators (Signe was a professor, while Elizabeth and Sue Ellen were graduate students) working at the same university from 2016-2018. We acknowledge that teacher education in the United States during this time period was informed by teacher accreditation systems. Assessment systems for teacher education program improvement were in place, but dynamic. Teacher educators were charged with contributing rubrics and assignments that served to support PTs' development of insight into teaching and learning, but also to assess PTs' development against defined criteria for that development.

\section{Signe}

Using autobiographies in a university mathematics course, helped me gain insight into my students' feelings about mathematics and doing mathematics. I learned to work with PTs to unpack the emotional load of learning what society has come to accept doing mathematics in school looks like and means. PTs accepted common binaries of society as they described being good or bad at mathematics and either liking it or hating the subject. These stories often positioned PTs as receivers of approaches to teaching mathematics as arrogant, playful, or frightening. When I began teaching about teaching (Loughran, 2004) in mathematics methods courses, I no longer saw the value in autobiographies. I reasoned that mathematics histories impacted learning about mathematics, rather than learning about teaching. I dropped autobiographies until our reading group (Elizabeth and Sue Ellen) began to ponder the sense of past, present, and future that might be informing PTs' lesson planning and teaching. Sue Ellen and Elizabeth designed the teacher story assignment that I included in the first week of activity in mathematics methods.

\section{Elizabeth}

The fall of 2016, I was working on my dissertation proposal and Signe invited me to work with her in her methods course for prospective elementary mathematics teachers. This was the first time I was a teaching assistant (TA) for Signe and I was excited to have some experience with PTs in the U.S. Around the same time Sue Ellen, Signe, and I were doing some readings together (i.e., CLANDININ \& CONNELLY, 1994; CLANDININ \& CONNELLY, 2000; DEWEY, 1938; ELBAZ, 1981). I particularly remember reading Clandinin and Connelly's (1994) experiential method chapter. I borrowed it from the library, scanned it, and shared Sue Ellen and Signe. One method that caught my attention was the lifeline or annal. Clandinin and Connelly (1994) described the lifeline as a reflection tool that researchers can create to engage with participants. You describe moments of episodes of your life that are relevant and, if it is possible, you complement these moments with artifacts such as pictures of those moments. Signe invited me to try this in her classroom. That was my first assignment as a TA. In the summer of 2016, Sue Ellen and I worked on designing what we called the teacher story assignment.

Although I was excited to use this "method to collect data" for my dissertation study, I ended up more excited about the possibility of implementing it with the PTs. I remember that sharing our teacher stories was a special moment. We told stories of ourselves as daughters, learners, and teachers. It was a moment to be with each other, of knowing, and feeling.

\section{Sue Ellen}

Signe wants to use the annal in the elementary methods class. Can be extrapolated into the future. PSTs make posters to introduce themselves to the students, but Signe thinks this annal idea would be even better. (Sue Ellen's 
note from CLANDININ \& CONNELLY; 1994, p. 420; MARCH 23, 2016)

We initially were thinking about the PTs using the stories as a way to introduce themselves to the children in their field experience classrooms. In some early childhood schools, the teachers post biographical information in a prominent location so families can begin to know them. Additionally, the epistemology theories that resonate for me are grounded in experience and often in stories. I was inspired by the idea of making second-order models of learners when learning about radical constructivism (VON GLASERSFELD, 1995). Reading my students' stories of their experiences learning mathematics had the potential to fill in more of the model I made of each learner in my class and to formalize the anecdotal work I had done for years. But mostly, I have found that I story myself in order to make meaning of my experiences, and I collect others' stories as we make meaning together. Through this assignment, I hoped to provide an opportunity for my students to gain insight from their past and present mathematical learning and teaching experiences to build on as they prepared to become teachers. I have used the assignment since Elizabeth and I created it in the summer of 2016 and continue to learn about what my students can tell me through, and can learn from, their stories.

\section{Methodology and Methods}

In this section we begin with a discussion of our view of self-study methodology. We then turn to methods we used in the study including the use of critical friendship in a book study, data analysis, and how we represent our findings.

\section{Self-Study Methodology}

Self-study in relation to teaching and teacher education practices has emerged from the work of teachers and teacher educators themselves. That is, that their attempts to better understand the problematic worlds of teaching and learning have led to an increasing focus on their work so that researching their practice better informs them about their teaching and enhances their students' learning. (LOUGHRAN, 2007, p. 9)

We use self-study methodology, developed to explore and communicate about "teaching about teaching" (LOUGHRAN, 2004) to investigate our motivations for and insights from the use of teacher stories as an MTE practice. Drawing from Samaras and Freese (2009), we characterize self-study using the terms openness, collaboration, and reframing. We understand the use of openness on two levels, ways in which we make our practices open to each other during our discussions of teaching and ways in which we make our practices open to readers in sharing our findings. Collaboration for us involves engaging in the discussion of our practices. Beyond collaboration as a mechanism for sharing our practice, our discussions also become data for our self-study (LABOSKEY, 2004). These discussions result in reframings of our understandings of our practice and reframings of the questions we ask about our practices. The result of our analysis of artefacts from our teaching and our discussions are then represented to first and foremost inform and improve our practices, but further to add to conversations about teacher stories in the mathematics teacher education literature (VANASSCHE \& KELCHTERMANS, 2015).

\section{Context: Critical friends and book study}

Schuck and Russell (2005) describe the essential need for critical friendship in self-study. "A critical friend is a significant part of a self-study. Both practitioner and critical friend should 
support and challenge each other to ensure that relevant perspectives are brought to bear on the self-study" (p. 120). Our exploration of motivations for our use of teacher stories involved two sorts of critical friendship: attention to supporting and challenging perspectives we each raised and challenges to our perspectives raised by the writings of Dewey and Rogers. While the three of us were involved in teacher education in the same academic context, our relationship as critical friends varied dynamically. Sue Ellen and Signe had known each other for many years and across institutional contexts. We had worked together in two different universities, but in similar relationships. Signe played an administrative role in both contexts. This description does not convey all the feelings involved in the relationship Sue Ellen and Signe had. They had worked together discussing teaching practice and family experiences in ways that encouraged the growth of a caring friendship. Elizabeth joined the group as a result of her enrollment in a PhD program. She and Sue Ellen developed a relationship as fellow graduate students. In 2016 Sue Ellen and Elizabeth worked as teaching assistants (Sue Ellen teaching a section of mathematics methods and Elizabeth working with Signe in her section) for mathematics methods that Signe coordinated. Based on our discussions and shared curiosity about narrative inquiry, we began discussing various books (i.e., CLANDININ \& CONNELLY, 1994; CLANDININ \& CONNELLY, 2000; DEWEY, 1938; ELBAZ, 1981) to build our background in narrative inquiry and to gain insight into our practices. While we were studying Dewey the idea of teacher stories emerged in planning for the Fall 2016 sections of mathematics methods. Initially we were unaware of the role of our book studies in our development of the teacher story activity. As we began exploring our motivations for including teacher stories in our practice, we came to view our book study of Dewey (1938) and Rogers (1961) in the context of critical friendship.

Critical friendship, while typically engaged in by living and corresponding colleagues, may involve "distant" more knowledgeable others (STOLLE, FRAMBAUGH-KRITZER, FEESE, \& PERSSON, 2018) such as authors of articles or books. Dewey and Rogers served as provocateurs. During each meeting, we shared passages from the readings that confused or inspired us. We then discussed meanings of the readings in the context of our lives and work. We focused in on experience, told stories from our experience that we hoped would illuminate our understanding of the reading, and discussed the role of the MTE from the position of the Dewey and Rogers.

\section{Dewey as a more knowledgeable other}

Although $21^{\text {st }}$ century educators seem to know that experience influences learning outcomes, how to make sense of the complexity of experience and how to support a development of experience to encourage the construction of a practice from experience (MUMBY \& RUSSELL, 1994) was unclear to us. Our reading of Dewey's (1938) “Experience and Education," helped us probe our stances on the role of experience in our MTE practices. Dewey's principles of experience, continuity and interaction, captured our attention. We wrestled with the notion of the continuity of experience. We assumed that PTs' past experiences have implications for their present and future, but also that experiences PTs have in mathematics methods have this same quality. The notion of creating experiences with PTs was the focus of many discussions. We wrestled with our perspectives of ourselves as MTEs and our students as humans and PTs.

For example, 
As I [Elizabeth] read Dewey, I resonated with his ideas about education. Before reading Dewey, I did not have a language to describe people's unique ways of being. I wondered why two people with the same educational background might have different teaching practices. Dewey provided me the language to talk about the relevance of experience in education.

If a person decides to become a teacher, [...] when he executes his intention, he thereby necessarily determines to some extent the environment in which he will act in the future. He has rendered himself more sensitive and responsive to certain conditions, and relatively immune to those things about him that would have stimuli if he had made another choice (DEWEY, 1938, p. 37).

Dewey's description made me aware of the role of our histories in our teaching. In my teaching, I would prioritize certain things because of what I lived before. Reading this brought me to understand that our lived experiences are not just part of our memories, but they become sources of the decisions we made, and the things we decide to focus on.

Accompanying the continuity of experience was the idea that all experience involves interacting with objects and people. Such interactions in mathematics teacher education can be informed by structures set by the MTE. We had little difficulty thinking in terms of activities we set for prospective mathematics teachers, but we wondered how the PTs' experiences were a source of insight in our design of such activities. Whether we consciously constructed the activities with insight into PTs' experiences with teaching and learning mathematics or not, we understood that "every experience lives on in future experiences" (DEWEY, 1938, p. 27). Our understanding of this principle of the continuity of experience made our desire to understand the experiences of PTs and to build experiences that had the potential to contribute to future activity and insight upon reflection became central in our work as MTEs.

\section{Rogers as a more knowledgeable other}

In our reading of Rogers, we focused on the notion of congruence and the danger to relationships when evaluation is part of the context for the relationship. While Rogers work is situated in psychotherapy and focused on client-centered therapy, he described characteristics of relationships in general that support "growth, enhancement, openness, and development of individuals" (p. 339). Here we use Rogers' ideas of process and evaluation, as we came to understand them through conversations, to inform our view of "relational practice" (GROSSMAN et al., 2009) and ourselves as relational practitioners.

Rogers' description of interpersonal relationships was crafted from the perspective of a psychotherapists to inform "psychological growth" (p. 339). We take up Rogers ideas and make sense of them in mathematics teacher education rather than in psychotherapy. We view the characteristics of relationship Rogers describes as central to all relationships. Rogers described congruence as a characteristic of the relationship and from the perspective of the teacher when the teacher "is genuine and without 'front' or façade, openly being the feelings and attitudes which at that moment are flowing in him" (p. 61). Wrestling with how to be genuine with our PTs in the domain of institutional structures that include teacher and student evaluation, became a focus of our conversations. The evaluative environment of our institutional context made us wonder how we could be authentic with the PT and communicate the second characteristics of a relationship as "unconditional positive regard" (p. 62). Such a regard seemed quite impossible to us even as we wanted to have this experience of "positive feeling without reservations, without evaluations" (p. 62). As we continued to turn over and over feelings we had for PTs and our- 
selves in various stories of our work with them, we considered how we took up empathy and how we had "empathic understanding" (p. 62). This kind of understanding is free of judgement and includes an understanding of "how it feels and seems to be me" (p. 62).

\section{Identification and Analysis of Our Field Texts}

Our field texts, or data, were reconstructions of three different sources: classroom artifacts, book discussions, and conferences proposals. Classroom artifacts were our syllabus, drafts of the teacher stories assignment, memories of class discussions, and selected feedback provided to our PTs. In addition, we compiled audio recordings of our conversations from reading Rogers' and Dewey's books, and our own journaling, or memories of our reflections from the readings. Lastly, drafts of conferences proposals and memories of our presentations are part of our field texts. The writing of such proposals brought us to new ways of knowing.

Our journey passing from field to research texts was characterized by the re-writing and re-living of our experiences with the teacher story assignment in light of our book discussions and insights drawn from revisiting the artifacts. Each of us took a different journey where we assigned personal meanings (POLKINGHORNE, 2007) to our past and current experiences, which at the same time brought us to re-envision our role as MTEs. We described these new ways of knowing ourselves, and their relationship to our practice as MTEs, with phrases that resonated with us and informed the plot of our research texts (Polkinghorne, 1995).

\section{Findings: Teacher Stories as}

\section{Touchstones for MTEs' Learning}

The findings from our self-study are repre- sented as three teacher stories. In these stories, we explore our ourselves and the way PTs' stories taught and changed us. The analysis of our field texts brought us to know ourselves, and our motivations for asking our PTs to write their teacher stories. By writing our own teacher stories, we represent ourselves to us, and to each other, in a way that communicates our humanistic ways of knowing (SCHON, 1983).

\section{Signe: Being Seen and Seeing}

I was always the loud girl. You know the one. You can hear her on the train, plane, or even walking down the street. Second hand talk, loud and proud, having a conversation and not afraid to show it. My father was always trying to get me to be quiet. "You're too loud! Turn it down." Then something happened. I'm not really sure what or when, but by the end of high school I was the shy girl. Trying to be invisible and blend in. Sitting on the side, in the back, anywhere not to be noticed. Being invisible is hard to accomplish when you are the teacher. Student eyes find you and they giggle a little or look away. I assumed it was about me.

Sue Ellen and Elizabeth were graduate teaching assistants. We worked together teaching mathematics methods for elementary teachers in the Fall of 2016. I had known Sue Ellen for quite a long time at that point. She reminded me of my mother. We chatted together about things I never shared with anyone else. She asked me about my life and my children. Elizabeth was newer in my life. We had worked together in professional development and I had seen her talk with teachers. I saw her accept the teachers' ideas and work inside the boundaries of those ideas. She made suggestions about sources teachers might want to use, but only after listening to the teachers share their goals. When we decided to do teacher stories as a class assignment, Sue El- 
len and Elizabeth created the assignment. I just brainstormed with them about what should be included. Our goal was to gain insight into the PTs' lived experiences with mathematics. We planned to use the stories the PTs' told to situate teaching as a complex set of activities. We reasoned that the PTs' needed to understand that learners responded to mathematics activities in the same or different ways than the PTs had. In short, we planned to use the teacher's stories as levers to promote particular views of mathematics teaching and learning.

Sue Ellen, Elizabeth, and I continued to discuss our teaching and our use of teacher stories. I did not think about the assignment during Spring 2017, but instead wrote about myself and how I was seen.

I see and feel my life as an aging mother and wife in white middle-class America as devalued by systems of political rhetoric. My life as an academic feels more legitimate to me than my identity as a woman. As I develop my identity as a professor, I see my voice as my tool of action in society (KASTBERG, 2017).

I was not conscious of any connection between my writing in 2017 and my experience as a high school girl. These selves stood separately in time. Sue Ellen, Elizabeth, and I continue our book studies across 2017, gaining insight into the importance of experience. We continued to think about how to use PTs' experiences in our teaching. We wondered what the PTs' stories were telling us and how we might build on them. Elizabeth suggested that we could present our questions about the use of PTs' experiences at a conference. Sue Ellen, Elizabeth and I traveled to New York City for the conference on my birthday in 2018. My friends surprised me with a celebration at breakfast on the day of our presentation. The hotel dining room was small with other diners enjoying bagels. Elizabeth made a cake and even found a way to get a lit candle on top. I felt visible, important, and optimistic about the day. I looked forward to our presentation. This was quite uncharacteristic of me. I was typically nervous and worried about what audience members might say or ask. When the time came for our session, we worked as we had planned, asking audience members to break into pairs and discuss a series of question. Elizabeth was my partner. I recall her asking me why I use teacher stories. I did not know the answer. Yet I began talking and as I responded, I became aware of a deep need in me. I began to cry. I was the presenter. Elizabeth helped me through the end of the presentation. I turned my words over and over to find meanings, but none were obvious to me then. I told Elizabeth, "I want my students to know they are seen." I did not know why the tears came, only that the words drew them out of me.

About the same time Elizabeth, Sue Ellen, and I were reading Carl Rogers. We discussed how Rogers' ideas had meaning in our experiences as women and teachers. I was anxious to read his ideas about teaching and began discussing it with the group in May $\left(22^{\text {nd }}, 2018\right)$ before the chapter reading was due. I asked Sue Ellen to predict what Rogers might plan as he prepared for a class. Sue Ellen shared her insights about Rogers as setting up the environment. I laughed as I thought aloud about the sort of teaching Rogers had described.

Signe: Can you imagine?

Sue Ellen: Doing that?

Signe: So we go in the first day and say, "So what do you guys want to learn? You guys need to work on that. Let's work on that. Let me know when you have something or if you need some resources, just ask me for them."

Sue Ellen: laughs

Signe: (goes on talking like the teacher) "Okay how far have you gotten on your activities that you want to do this semester? Are there any 
resources you want me to get for you? I'll be here. You should work together to come up with something."

Sue Ellen: Well he sets a background. He set like, I don't know I haven't read the chapter.

Signe: I was just wondering, so when I am thinking about how he would teach a class, I imagine some students being very unhappy.

Sue Ellen: Because he doesn't have any structure and he doesn't...?

Signe: Yeah. He would teach like I would "hypothetically" teach, except I would have to have some activities. I'm sorry I just have to. But the activities would always be informed by the students.... (51:43-53:02)

In this excerpt from our discussion, I see myself playing with the idea that I might teach like Rogers or like me, using the sort of approach Rogers describes. I wondered how the students would see me. Could they see me through my activities? In this conversation Dewey's notion of experience, the PT's experience, was central. I saw my experience as a teacher becoming invisible. Did I need to fade to the back of the class?

The fall came and my class was small. Very small, only ten PTs. With such a small class, I felt I had the best chance to know the PTs as people. Each week Sue Ellen and I talked about our PTs and how their stories informed our thinking. I tried to find ways to see PTs developing views of mathematics teaching and learning. We discussed ways PTs reached out to us or the way we offered our experience to them. Sue Ellen again pointed to our offering of resources as a way we were showing empathy and creating a sense of congruence, as described by Rogers. One pair of PTs captured my attention with a series of lessons that sought to teach children how to use the number line as a tool in subtraction. I offered resources as Sue Ellen and I had discussed. After each les- son, I inquired into observations the PTs had made about the children and their actions. During one such inquiry, the PTs' words raised a question for me about how the children were coordinating the counting sequence with one unit jumps on the number line. I asked the PTs what they thought. For me it was an open question. What part of the jump was coordinated with the utterance of the number word? Later that week, I received an email from one PT asking for resources discussing the use of models in learning mathematics. I was anxious to share this with Sue Ellen, but we did not have a scheduled meeting. A week later, when I read the PT's analysis of her teaching, none of the resources I had sent were referenced. The course was ending. Unexpectedly, the other PT in the pair asked to meet me for coffee. It was during this conversation that I learned about this second PT's impressions of my question about coordination. She had become even more curious about the ways the children coordinated their counts and jumps and had explored these ideas in her paper, without the use of new references from me. When Sue Ellen and I finally met, I was bursting to share these two experiences. I wondered if offering resources has any effect on the PTs. Before the experience with these two PTs, I had assumed that when a PT asks for resources, they are seeing my value and reaching out. Being asked for resources seemed to signal a valuing of me, that my offering of resources did not. Yet as I thought about the two PTs, I had begun to wonder. Sue Ellen drew me back to Rogers and the offer of resources as the PTs complete their own inquiry. I began to make sense of ways I was seen by the PTs. It seemed to me I was seen in different ways by these two PTs as a resource for materials and articles, but also as a collaborator in the exploration of ideas. I could find resources, but also serve as a resource for reflection. I saw myself in support of 
both PTs. Each drew from me what they needed. Each needed me differently. Each PT was different, as they had tried to tell me through their stories.

I still don't know how I became invisible. I can hypothesize about the reasons and the ways, but I'm not sure they matter as I work to build relationships with PTs. How am I seen? Can I see myself? How do I see myself? These are the questions I wrestle with as I listen to teacher stories and live the experience of being a resource and coming into view.

\section{Elizabeth: A Way To Teach}

When I was doing my student teaching in Chile, I was asked to teach an afterschool mathematics class. I recall teaching geometric transformations, such as rotations and translations, to a class of mostly male students. One day, I was called to the principal's office. The school corporation had sent a visitor for the day, a psychologist. The principal introduced me, and the psychologist and I started talking around a table that was relatively far from the principal's desk, but still in the same room. As I write this, it amazes me that I did not care about the principal being next to us. The psychologist started asking me about the students from my class. He said something like, "do you know that these are misbehaved students?" I responded "No, I did not know that. They seem like normal students to me, I have not had any problem with them." Then, the psychologist described my teaching. He referred to an artist who sculpted a statue from a rock and treated the statue as a human to the point that the statue became a human. He said to me, "You treat these students as good students, and they seem to respond as such." At that time, I thought, “Isn't that what a teacher is supposed to do with her students?" The psychologist's comment made me feel uneasy. I felt proud of myself for my approach with the students, but something did not feel right. The psychologist did not know me. He could have said that to anybody. I was also in the principal's office. Would the psychologist say something different to me in front of the principal? Was he secretly evaluating me? I return to this memory often as I think it has influenced my way of being with students.

My view of education has changed over time as a result of reflecting on its role and how teacher education could look. I thought that teachers had the responsibility to teach students, creating spaces for students to learn mathematics. My memories of methods courses were doing some teaching that was later discussed with classmates or the methods instructor. I learned about different planning templates and types of assessments. Yet, I did not feel that I was getting what I needed, a way to be a teacher. The only person who told me how I was as a teacher was that psychologist, and that did not feel right to me.

Later, I thought that knowing more mathematics was key to be a good mathematics teacher. This was one of the reasons I pursued a master's degree in pure mathematics. I thought that by learning more mathematics, I would have a broader perspective, which would help me to create learning spaces for my students. Far ahead, I wanted to learn about research in mathematics education and I came to the U.S. to pursue a doctorate. I thought that I was going to solve the problem of education by learning how to do educational research. I thought there was a way to teach that I could only get from academic training. Yet, while learning about research in mathematics education, I became aware of the role of teachers' lives in schools and in their teaching. This brought me to think that tasks were a way to teach. Once again, I learned that tasks by themselves were not enough, that teach- 
ers' roles and personalities were important elements. In the middle of my exposure to the U.S. educational system and to research, my memories of my teachers, and myself teaching back in Chile, reminded me of the importance of teachers' practical ways of knowing in classrooms. This was a counterbalance to the narrative I had been exposed to. It was not until I was Signe's TA in her methods course, listening to her PTs' experiences, that I started thinking about methods courses in a different way. My past self as a PT resonated with the 2016 PTs' stories and complaints. PTs perceived a huge dissonance between their academic work at the university and their teaching practice in schools. PTs wanted to know many things and not knowing made them feel overwhelmed. I resonated with their feelings. That is how I felt when I was taking my last methods course and even after knowing more mathematics. I thought I was going to be taught how to teach and be with my students. I thought I was going to learn this through my teacher preparation and mathematics preparation programs. And, there I was, in front of American PTs, with multiple educational certificates, still not knowing how to teach them to be teachers.

When I was a student teacher, I was not thinking, "Oh these students behave badly, so that I am going to treat them as good students." I do not remember someone in my teaching preparation program telling me to do that either. That past self was just being with the students and loving being with them. Preparing my teacher story for PTs brought up my memories as a person and teacher. I have been a caring teacher and person. I care for my parents and relatives. I think caring is my essence as a person. I always want to help, make others feel good, and promote those ways of being in others. If I start thinking about why I am this way, I could identify many reasons, but I am not certain of a reason. I remember my father donating school supplies to a neighbor, even when we did not have much for ourselves. I remember my primary school teacher parking her Citroën car in front of our home to bring clothing for me. I loved wearing a white blouse with big flaps she gave me. I remember my grandmother giving us fresh vegetables and fruits from her garden every summer. I grew up experiencing people's caring toward me and to others. There is also a part of myself that is brave and always ready to defend others. I remember myself as a teenager defending people from, what I considered, injustices. I went to talk to my father's boss because he did not fulfill a promise he made to my father. I remember defending my aunt-in-law from my uncle's aggressive reactions towards her. I remember going to rescue my brother's bike from neighbors that stole it. All those experiences might have brought me to be who I am as a person and teacher. Yet, when I am teaching, I am not thinking about them and their impact on my way of being in the classroom. Moreover, I could not see the connection between my way of being as a person and my way of being as a teacher. I saw teaching as a mostly academic activity, (i.e., using different pedagogies, assessments and planning methods, and ways of communicating with students). This way of envisioning teaching was not connected to who I was as a person (e.g., being a caring person). I did not even want to talk about it because it was too personal, not academic.

Reading Dewey, I learned that paying attention to experience was important, but I did not really know how to use that knowledge in practice. Readings Rogers, I learned that people are not necessarily aware of the role of their experiences in their ways of being and this slows their process of becoming a full person. "The incongruence between experience and awareness is vividly experienced as it disappears into congruence" (ROGERS, 1961, 
p. 148). Reading Rogers, I reflected on how we become mature and learn to hide our feelings and live according to external evaluations. People do things because of tradition, anticipating evaluation from others, or lack of authenticity with their feelings. Many times, this starts by oppressing feelings. Discussing Rogers and writing my reflections about it, I learned that I was seeking external validation for my teaching and I thought I was going to find it by getting academic training. Yet, this felt incongruent with the way I knew teaching by heart (NOLAN, 2007). I realized that I had two contradictory teaching images. I was a caring teacher and believed in my students no matter what. Yet, I valued academic knowledge and wanted to be taught $a$ way to be a teacher, some kind of recipe given to me by an academic institution. I studied, studied, and came to understand that when we refer to the field of teacher education, there is no recipe or a way to teach. Even experienced people in academia have recognized feeling uncomfortable when positioned as the deliverers and evaluators of propositional knowledge in PTs (e.g., CLANDININ, 1995; ELBAZ, 2014).

When the 2016 PTs expressed their concerns before going into the field for the first time, their stories resonated with me. I responded with care and was with them in their moments of concern. I did not think about not being academic or rejecting their concerns. I embraced them and started supporting them in their search for help. Yet, I did not see my actions as part of being an MTE. My discussions with Signe and Sue Ellen awakened me to the way in which the educational system brought me to think that there was a way to teach and that I was going to learn it from academic institutions. Like my own past self, the 2016 PTs wanted to be taught a way to teach. Now I see my role of MTE as being with PTs in their process of becoming, acknowledging that we, the instructors, do not have to have all the answers for their questions or concerns. I understood that my role was to provide spaces for PTs to explore their teaching interests that now I envision as rooted in their lived experiences.

Writing a teacher story is a process of re-living and re-telling our experiences, as I did in this writing. Re-writing and re-telling are what took me into the congruence path that Rogers (1961) described. It is the space to re-consider the meaning of our experiences with our ways of being. Writing our teacher story is an internal exploration into our personal practical knowledge (ELBAZ, 1981). My role as an MTE includes creating spaces for writing, reading, and sharing teacher stories as a way to be with my students, and acknowledging them, no matter their state of life or academic knowledge. It is also my opportunity to show my care for them, which made me feel sustained.

\section{Sue Ellen: Seeking Permission}

Growing up, having permission was important in my family, asking after every meal, "May I please be excused from the table?" The first time I co-taught early childhood math methods, my understanding of learning theory required that students construct their own understanding, which did not give me permission to help a student struggling with a fraction problem, making everyone in the room miserable. Following is a story of the evolution of my seeking permission.

I have known Signe a long time. She has been a mentor to me throughout my doctoral studies, and I have looked to her for guidance throughout our relationship and time together, sometimes asking her directly and other times imagining what she might do in a situation. Elizabeth joined the program after me. We worked together on a project with other graduate students and found some resonance in our ways of knowing. The three of us later 
found that we shared curiosity about the role of experience in research and in teaching and learning, which led us to read Dewey's Experience and Education (1938/1998) together.

There was one passage in the book that I marked. In my development as an early childhood teacher, I learned to take the child's lead, which fit well with the constructivism learning theory from my later doctoral program. With my elementary mathematics methods students, in addition to not answering questions directly, this meant that I often did not feel permission to provide resources unless they asked. I started making connections in my work when Signe, Elizabeth, and I began discussing Dewey's (1938/1998) ideas. I connected my understanding of the early childhood learning environment described as the "third teacher" (informed by Reggio Emilia theory) (Edwards, Gandini, \& Forman, 1998), reading about Rogers (1961) setting the learning environment, and a quote from Dewey that could have been written about me. My work with these readings finally began to give me the permission to trust that my role is to provide something for my students, because I have more experience. Dewey stated:

I have heard of cases in which children are surrounded with objects and materials and then left entirely to themselves, the teacher being loathe to suggest even what might be done with the materials lest freedom be infringed upon [this was totally about me]. Why, then, even supply materials, since they are a source of some suggestion or other? But what is more important is that the suggestion upon which pupils act must in any case come from somewhere. It is impossible to understand why a suggestion from one who has a larger experience and a wider horizon should not be at least as valid as a suggestion arising from some or less accidental source (1938/1998, p. 84).

With permission given by Dewey, I began finding resources for my students to help them plan mathematics lessons and to make sense of children's actions and work during their teaching. My student, $M$, sent her lesson as required, and I gave her the following feedback:

Hi M,

Your lesson looks good. The last box is empty on your plan. What are you thinking you would like to hear from your students?

I didn't find a lot of information about multiplicative comparison, except for the 2 short documents that are attached. The way your lesson is structured, it looks like the children will only do one problem. This is fine. Do you have manipulatives for them to use, or will you encourage them to draw? I found an interesting problem about the amount of allowance two boys received, one was additive and one was multiplicative. There was a drawing that showed how the amounts increased over time, and it looked so interesting, especially since your goal is for the children to think about the difference between additive and multiplicative comparison.

OR you can use your original problem! It's fine. I was just trying to find a way to do additive comparison and multiplicative comparison in the same problem.

\section{Sue Ellen}

She thanked me for the feedback and incorporated it into her lesson. I was excited to see $M$ teach the lesson. She was also excited as she began teaching, but as she proceeded through her revised plan, dismay seeped across her face and interactions with her students. After reading her analysis of her teaching, I again gave her a resource and instructions for revisions. In the end, $M$ did not use any of the resources I provided for her analysis. I felt awful that the revisions I suggested for her lesson felt disastrous to her, and I was confused about why she did not use the resources I had provided for her analysis.

The story of M's lesson came to mind as Signe, Elizabeth, and I discussed Rogers' (1961) 
constructs of congruence, unconditional acceptance, and empathic understanding. The congruence I felt with $M$ gave me permission to provide resources to her, but I wondered how well I tried to understand her thinking and perceive her experiences as she planned and analyzed her lesson. I began to see that she felt an obligation to accept my suggestions for her lesson and might have rejected them in her analysis because they did not work for her while teaching her lesson. Re-reading M's teacher story looking for ways my feedback might have been more useful, I found an experience from M's past that seemed to foreshadow the feelings behind her expression while she was teaching "our" lesson. M shared in her story that as a sixth-grader, she felt "dumbfounded" when her classmates used a computing "trick" they had learned before she joined their class. Finding M's feelings of being "dumbfounded" as she realized she did not know the trick and, during her lesson, did not know what the students' responses to the tasks in her lessons meant, showed me that I could use teacher stories differently. I am excited to intentionally look for these clues in PT's stories in the future.

This story of M's lesson stands out in my mind because I acted on the newfound permission I felt, and it seemed to backfire. But rather than retreating to my previous tendency to fear imposing my ideas on my students, I told Signe and Elizabeth my story of M's lesson. This retelling supported me to see myself and ways I could interact with PTs in the future. I feel that Signe and Elizabeth and I subconsciously practice the Rogers (1961) characteristics for supporting another human, especially during our meetings together. Each of us works to be in congruence with ourselves, accepts each other as we are, and attempts to feel what each other feels. After these episodes of practicing the way we want to be with others for an hour or so, I find my interactions with others are a little bit more accepting than before, and I am capable of feeling another's situation with a little bit more detail. This time spent practicing together is therapeutic in helping me accept myself in process and gives me permission to be me.

Now I see two roles for the teacher story project, one for PTs and one for me. For my students, my goal is to provide a safe space for them to re-story, explore, and interpret their previous mathematics experiences through their current experiences learning and teaching mathematics with children. As the MTEs for the course, we set the overarching structure/ environment that includes the course activities, course assignments, and instructional activities PTs will engage in with children in schools. In my interactions with PTs, my role is to discern their purposes and experiences (DEWEY, 1938/1998) in order to provide a suggestion, a resource, that will resonate in some way with their past and current experiences and provide an opportunity for PTs and myself to learn together. To execute this role, I must accept myself as I am, accept PTs as they are, strive to sense how PTs could be feeling, and communicate my understanding of their feelings back to them (ROGERS, 1961). For me, this has meant removing my own agenda in these interactions. While I expect PTs to use literature to support claims they make, for example, I have come to realize that I might first listen to their ideas about their teaching, then provide resources without assumptions about how PTs will use them.

While I am aware of this evolution in my interactions with my students, I have not been so aware of my own self-acceptance, which has been a long, tedious journey. Being with Signe and Elizabeth has allowed me to feel permission to experience my own feelings and ways of thinking. But as I have let go of the responsibility to produce a "right" answer, I 
have struggled to articulate my own answer. It feels weird, ungrounded. This, I think, is Rogers' process of becoming. So I talk with my colleagues, working out the story and its meaning for my current understanding. Which is the opportunity I hope the teacher story project can provide for PTs.

\section{Discussion}

The exploration of teacher stories reported in mathematics education literature illustrates ways such stories are used by MTEs as powerful levers for motivating change in PTs' current views of teaching and learning (de Freitas, 2008; Marshall \& Chao, 2018) and in PTs' behaviors as teachers (DRAKE, 2006; DRAKE \& SHERIN, 2006). MTEs' uses of teacher stories acknowledges the role of experience on the development of teacher identity (de FREITAS, 2008). The construction of teacher stories creates opportunities for PTs to make sense of knowledge for teaching as reaching beyond propositional to experiential and emotional knowledge. Our findings illustrate ways that motivations for the collection of teacher stories can change. In particular we found that our initial collection and discussion of PTs' teacher stories was self-serving, to empower our own teaching, or research. We considered how PTs' stories might help us know PTs and how knowing PTs' stories could be useful in discussions of and plans for teaching. We envisioned knowing about the lived experiences of PTs as allowing us to insinuate ourselves into PTs' experiences designing and teaching mathematics lessons. We view this finding as in alignment with the use of stories as a lever to motivate changes with an end goal in mind, such as reform teaching (DRAKE \& SHERIN, 2006) or support of social justice (de FREITAS, 2008). In addition, we found that our motivations for collecting such stories shifted as we experienced awakenings (CONNELLY \&
CLANDININ, 1994, 1995) to more personal insights about ourselves as teacher educators.

As we look across our teacher stories, we identify the role of evaluation in all three stories. In an environment of evaluation (Rogers, 1961), humans feel the need to hide parts of their identities to feel that they belong. In teacher education in the United States, accreditation requires that university teacher education programs have assessment systems. Program areas then use these systems to evaluate PTs development and find areas for program improvement. On its face, such evaluation is a powerful tool to improve teacher education practices and programs. Yet, because the results of such assessment systems are evaluated by external bodies, teacher educators can focus on easily measurable changes in PTs such as propositional knowledge and observable behavior. Engaging in national and local discussions of measurable outcomes influence MTEs' practices and views of self when their programs are identified as "exemplary" or "needing improvement." It is in such contexts that MTEs' collection of PTs' teacher stories play out. The context of evaluation can motivate the need to use such stories to move PTs toward particular practices, values, and attitudes. The stories of Signe, Elizabeth, and Sue Ellen illustrate the ways evaluation informed who they were as people and teachers. Signe had become invisible, Elizabeth believed there was a way to teach, and Sue Ellen sought permission. We doubt that practices drawing from these senses of self could be sustained.

Exploring our motivations to invite PTs to write their teacher stories, in light of our book discussions, awakened us to the challenges of being MTEs in an academic world that portray us as the deliverers and evaluators of propositional knowledge (DOYLE \& CARTER, 2003). We continuously feel the pressure to "move" PTs toward "productive teaching practices," almost 
as if these were objective and ahuman. This pressure is part of the culture of accountability and evaluation, and the need to be seen as effective and successful. Yet this desire contradicts our conscious drive to create opportunities in which PTs can create their own stories of learning to teach. This prompted us to re-imagine our roles as MTEs. For Signe the need to know PTs, so she could teach them something she valued gave way to motivation to be known and to be of use to PTs. For Elizabeth, creating spaces for PTs to inquire into their personal practical knowledge (ELBAZ, 1981) rather than trying to teach them ways to teach became the motivation for stories. For Sue Ellen, through the readings and feeling permission from her colleagues, the teacher story is an early opportunity to experience acceptance from the PTs during their time together. We envision teacher stories as a mechanism to learn about ourselves and to be with our PTs in their journeys of becoming (DOYLE \& CARTER, 2003). This new role makes us feel in congruence (ROGERS, 1961) with ourselves and our work with PTs.

\section{Conclusion}

Our motivations to invite PTs to write their teacher stories were informed by our views of teaching and learning, and these evolved in light of our discussions of Dewey's and Rogers' books. This article illuminates the potential for teacher stories as a counter-narrative to the role of teacher education programs as training or developing propositional knowledge. In this new narrative, MTEs and PTs are portrayed as learners of their practical ways of knowing.

\section{References}

CARTER, Kathy. The place of story in the study of teaching and teacher education. Educational researcher, v. 22, n. 1, p. 5-12, 18, Jan. 1993. Available at: <https:// doi:10.3102/0013189X022001005>. Ac- cessed: 29 Jan. 2019.

CLANDININ, Jean. Still learning to teach. In: RUSSELL, Tom; KORTHAGEN, Fred. (Eds.). Teachers who teach teachers: reflections on teacher education. Great Britain: Falmer Press, 1995. p. 25-31.

CLANDININ, Jean; CONNELLY, Michael. Teacher as curriculum maker. In: JACKSON, Philip. (Ed.). Handbook of research on curriculum: a project of the American Educational Research Association. New York: Macmillan Publishing Company, 1992. p. 363-401.

CLANDININ, Jean; CONNELLY, Michael. Personal experience methods. In: DENZIN, Norman; LINCOLN, Yvonna. (Eds.). Handbook of qualitative research. Thousand Oaks, California: Sage Publications, 1994. p. 413-427.

CLANDININ, Jean; CONNELLY, Michael. Teachers' professional knowledge landscapes: teacher stories - stories of teachers - school stories - stories of schools. Educational researcher, v. 25, n. 3, p. 24-30. 1996.

CLANDININ, Jean; CONNELLY, Michael. Narrative Inquiry: experience and story in qualitative research. San Francisco, CA: Jossey-Bass, 2000.

CONNELLY, Michael; CLANDININ, Jean. Telling teaching stories. Teacher education quarterly, v. 21, n. 1, p. 145-158, Winter 1994.

CONNELLY, Michael; CLANDININ, Jean. Narrative and education. Teachers and teaching, v. 1, n. 1, p. 7385, 1995. Available at: <https://doi-org.ezproxy.lib. purdue.edu/10.1080/1354060950010106>. Accessed: 29 Jan. 2019.

D'AMBROSIO, Beatriz; KASTBERG, Signe. Giving reason to prospective teachers. For the learning of mathematics, v. 32, n. 3, p. 22-27, 2012.

DE FREITAS, Elizabeth. Troubling teacher identity: preparing mathematics teachers to teach for diversity. Teaching education, v. 19, n. 1, p. 43-56, Mar. 2008. Available at: <https://doi.org/10.1080/10476210701860024>. Accessed: 29 Jan. 2019.

DEWEY, John. Experience and education. New York: Simon \& Schuster, 1938.

DEWEY, John. Experience and education: the 
60th anniversary edition. West Lafayette, Indiana: Kappa Delta Pi, 1938/1998.

DOYLE, Walter; CARTER, Kathy. Narrative and learning to teach: implications for teacher-education curriculum. Journal of curriculum studies, v. 35, n. 2, p. 129-137, 2003. Available at: <https:/ /doi:10.1080/00 $22027022000023053>$. Accessed: 6 Jan. 2019.

DRAKE, Corey. Turning points: using teachers' mathematics life stories to understand the implementation of mathematics education reform. Journal of mathematics teacher education, v. 9, n. 6, p. 579608, 2006. Available at: <https:/doi.org/ 10.1007/ s10857-006-9021-9>. Accessed: 29 Jan. 2019.

DRAKE, Corey; SHERIN, Miriam. Practicing change: curriculum adaptation and teacher narrative in the context of mathematics education reform. Curriculum inquiry, v. 36, n. 2, p. 153-187, June 2006. Available at: <https:/ /doi:10.1111/j.1467-873X.2006.00351.x>. Accessed: 29 Jan. 2019.

EDWARDS, Carolyn; GANDINI, Lella; FORMAN, George. (Eds.). The hundred languages of children: the Reggio Emilia approach--advanced reflections. 2. ed. New York: Ablex Publishing, 1998.

ELBAZ, Freema. The teacher's "practical knowledge:" report of a case study. Curriculum inquiry, v. 11, n. 1, p. 43-71, Mar. 1981.

ELBAZ-LUWISCH, Freema. Auto/biography and pedagogy: memory and presence in teaching. New York: Peter Lang, 2014.

GROSSMAN, Pamela; COMPTON, Christa, IGRA, Danielle; RONFELDT, Mathew, SHAHAN, Emily; WILLIAMSON, Peter. Teaching practice: a cross-professional perspective. Teachers College Record, v. 111, n. 9, p. 2055-2100, 2009.

KASTBERG, Signe. Teaching activity in the context of mathematical activity. Constructivist foundations, v. 13, n. 1, p. 183-185, 2017.

LABOSKEY, V. K. The methodology of self-study and its theoretical underpinnings. In: LOUGHRAN, J. John; HAMILTON, Mary Lynn; LABOSKEY, Vicky; RUSSELL, Tom L. (Eds.). International handbook of self-study of teaching and teacher education practices. Dor- drecht, The Netherlands: Springer, 2004. p. 817-869.

LEE, Hollylynne; MEWBORN, Denise. Mathematics teacher educators engaging in scholarly practices and inquiry. In: LEE, Hollylynne; MEWBORN, Denise. (Eds.). Scholarly practices and inquiry in the preparation of mathematics teachers. San Diego, California: Association of Mathematics Teacher Educators, 2009. p. 1-6.

LOUGHRAN, J. Researching teaching about teaching: self-study of teacher education practices. Studying teacher education, v. 1, n. 1, p. 5-16, May 2004. Available at: <https//doi:10.1080/17425960500039777>. Accessed: 29 Jan. 2019

LOUGHRAN, John. Researching teacher education practices: responding to the challenges, demands and expectations of self-study. Journal of teacher education, v. 58, n. 1, p. 12-20, Jan./Feb. 2007. Available at: <https//doi.org/10.1177/0022487106296217>. Accessed: 29 Jan. 2019.

LOPRESTO, Kevin; DRAKE, Corey. What's your (mathematics) story? Teaching children mathematics, v. 11, n. 5, p. 266-271, 2004.

MARSHALL, Anne Marie; CHAO, Theodore. Using mathematics autobiography stories to support emerging elementary mathematics teachers' sociopolitical consciousness and identity. In: KASTBERG, Signe; TYMINSKI, Andrew; LISCHKA, Alyson; SANCHEZ, Wendy. (Eds.). Building support for scholarly practices in mathematics methods. Charlotte, NC: Information Age, 2018. p. 279-293.

MEWBORN, Denise. Learning to teach elementary mathematics: ecological elements of a field experience. Journal of mathematics teacher education, v. 3, n. 1, p. 27-46, 2000. Available at: <https:// doi:10.1023/A:1009925728974>. Accessed: 29 Jan. 2019.

MUMBY, Hugh; RUSSELL, Tom. The authority of experience in learning to teach: messages from a physics methods class. Journal of teacher education, v. 45, n. 2, p. 86-95, Mar. 1994.

NOLAN, Kathleen. How should I know? Preservice teachers' images of knowing (by heart) in mathematics and science. Netherlands: Sense Publishers, 2007. 
NOLAN, Kathleen. Playing the field(s) of mathematics education: A teacher educator's journey into pedagogical and paradoxical possibilities. In: WALSHAW, Margaret. (Ed.). Unpacking pedagogy: new perspectives for mathematics classrooms. Charlotte, NC: Information Age Publishing, 2010. p. 153173.

POLKINGHORNE, Donald. Narrative configuration in qualitative analysis. International journal of qualitative studies in education, v. 8, n. 1, p. 5-23, Jan. 1995. Availableat:<https://doi:10.1080/0951839950080103>. Accessed: 29 Jan. 2019.

POLKINGHORNE, Donald. Validity issues in narrative research.Qualitative inquiry, v.13, n.4, p.471-486,June 2007. Available at: <doi:10.1177/1077800406297670>. Accessed. 29 Jan. 2019.

ROGERS, Carl. On becoming a person: a therapist's view of psychotherapy. Boston: Houghton Mifflin Company, 1961.

SAMARAS, Anastasia; FREESE, Anne. Looking back and looking forward: an historical overview of the self-study school. In: LASSONDE, Cynthia; GALMAN, Sally; KOSNIK, Clare. (Eds.). Self-Study research methodologies for teacher educators. Rotterdam: Sense Publishers, 2009. p. 3-20.

SCHIFTER, Deborah; FOSNOT, Catherine. Reconstructing mathematics education: stories of teachers meeting the challenge of reform. New York: Teachers College Press, 1993.
SCHON, Donald. The reflective practitioner: how professionals think in action. New York: Basic Books, 1983.

STOLLE, Elizabeth; FRAMBAUGH-KRITZER, Charlotte; FREESE, Anne; PERSSON, Anders. What makes a critical friend? In: GARBETT, Dawn; OVENS, Alan. (Eds.). Pushing boundaries and crossing boarders: self-study as a means for researching pedagogy. Self-Study of teacher education practices (S-STEP) - a special interest group of AERA, 2018. p. 147154. Available at: <http://portal.research.lu.se/ws/ files/47341605/What_makes_a_critical_friend.pdf>. Accessed: 28 Jan. 2019.

TZUR, Ron. Becoming a mathematics teacher-educator: conceptualizing the terrain through self-reflective analysis. Journal of mathematics teacher education, v. 4, n. 4, p. 259-283, 2001. Available at: <https://doi:10.1023/A:1013314009952>. Accessed: 28 Jan. 2019.

VANASSCHE, Eline; KELCHTERMANS, Geert. The state of the art in self-study of teacher education practices: a systematic literature review. Journal of curriculum studies, v. 47, n. 4, p. 508-528, 2015.

VON GLASERSFELD, Ernst. Radical Constructivism: a way of knowing and learning. New York: RoutledgeFalmer, 1995.

Recebido em: 03.02.02019

Aprovado em: 30.03.2019

Signe E. Kastberg Purdue University. Professor College of Education, Department of Curriculum and Instruction.

E-mail: skastber@purdue.edu

100 North University Street, BRNG 4128

West Lafayette, IN USA 47907-2098. Tel: +1(765) 494-2354

Elizabeth Suazo-Flores Purdue University. Post-Doctoral Research Associate Department of Biological Sciences. E-mail: esuazo@purdue.edu

915 West State Street, Lilly 3-219

West Lafayette, IN USA 47907-2098 Tel: +1(765) 494-4538

Sue Ellen Richardson Purdue University. Graduate Teaching Assistant. College of Education, Department of Curriculum and Instruction. E-mail: richa114@purdue.edu 